\title{
Consciência Planetária
}

Planetary Consciousness

Pedro A. Ribeiro de Oliveira*

A expressão "consciência planetária" tem sido cada vez mais empregada para dar conta de um fenômeno que, se não é propriamente novo, ganhou nos últimos anos uma dimensão surpreendente. Com efeito, seria impossível explicar os movimentos sociais que hoje se multiplicam em defesa da Terra, sem ter em conta o conjunto de ideias e valores que o fundamentam e levam tantas pessoas a tomar posição em favor da vida da Terra. Indo muito além da consciência ecológica, que se limita a assumir a responsabilidade humana pelo Planeta, a consciência planetária concebe a espécie humana como um componente entre outros no seu sistema de vida. Um componente que pensa, fala e de diferentes modos expressa sua consciência - e ao fazê-lo distingue-se das outras espécies -, mas que nem por isso pode arrogar-se o direito de considerar os outros seres vivos como coisas das quais se dispõe à vontade.

O uso do conceito de "consciência" pode gerar mal-estar no campo intelectual porque seu significado depende do contexto no qual é usado: basta pensar no que ele significa para a filosofia, a psicanálise, a medicina, a ética e a sociologia. Para a sociologia dos movimentos sociais, a "consciência planetária" relaciona-se com os movimentos em defesa da Terra, tal como "consciência de classe" relaciona-se a movimento proletário, "consciência feminista" a movimento de mulheres, "consciência da negritude" a movimento negro, ou "consciência nacional" a movimentos nacionalistas. Para todos esses movimentos a "consciência" é o elemento ideal que articula o autoconhecimento (quem somos), o conhecimento experiencial da realidade (o que é o mundo) e o critério ético para $\mathrm{o}$ agir transformador (em que aspecto esse mundo deve ser mudado).

A efetividade prática desse conceito, contudo, não dispensa a necessidade de submeter-se a um acurado exame teórico. Longe de ser um mero exercício acadêmico, a

\footnotetext{
* Doutor em Sociologia pela Universidade Católica de Louvain (Bélgica), pesquisador e professor do Programa de Pós-graduação em Ciências da Religião da PUC Minas. Membro da Comissão Editorial de Horizonte. País de origem: Brasil. E-mail: pedror.oliveira@uol.com.br
}

Horizonte, Belo Horizonte, v. 7, n. 14, p.9-11, jun. 2009 - ISSN 2175-5841 
crítica teórica é uma importante contribuição ao processo social, na medida em que alerta para suas possíveis ingenuidades e confusões. E não é outra a finalidade deste número da revista Horizonte: alargar e aprofundar o debate sobre o tema e assim contribuir para que os movimentos em defesa da vida do nosso Planeta possam melhor definir seus rumos.

Quem se volta para o estudo do tema logo encontra uma dificuldade: sua indefinição. Dada sua novidade e seu estado difuso, a "consciência planetária" não pode ser encontrada na realidade cotidiana, ou seja, não é possível apontar pessoas ou grupos que a representem com nitidez. Esse estado de fluidez favorece não poucos equívocos porque, não constituindo um sistema logicamente estruturado de ideias e valores, a "consciência planetária" pode agregar elementos tão díspares quanto a crítica ao especismo, a ética do cuidado, a prática de abraçar árvores, a dieta vegetariana, uma espiritualidade inspirada na Física quântica, a crença na "era de Aquarius", a teoria de Gaia, uma filosofia não antropocêntrica, a utopia da paz universal, a concepção evolucionista do cosmo... e a lista poderia ser aumentada à vontade. O problema maior é que todos esses elementos efetivamente cabem na consciência planetária, mas nenhum deles é indispensável para sua definição. Ela pode ter todos eles, mas, se não tiver, não deixará de ser uma forma de consciência capaz de fundamentar e motivar movimentos sociais em defesa da vida da Terra.

Para superar esse obstáculo ao estudo, o melhor é tomar uma de suas formulações como se já fosse uma forma paradigmática. Aí se impõe a Carta da Terra, ${ }^{1}$ cuja importância pode vir a ser equivalente à da Declaração Universal dos Direitos Humanos. Redigida por uma comissão formada por vinte e três homens e mulheres de destaque dos cinco continentes e tendo por base a contribuição de mais de cem mil pessoas, esse documento é referência para o movimento social global em defesa da vida do Planeta.

Elaborado em nome dos povos da Terra, esse documento pode ser lido como um manifesto que almeja o consenso mundial. Por expor imperativos de ordem ética, e não propostas de ordem política, ele evita abordar temas controversos. Assim, por exemplo, é contundente ao criticar a realidade de miséria, fome, violência e perda de qualidade de vida no mundo atual, mas omisso ao apontar suas causas: refere-se ao "crescimento sem precedentes da população humana", como se o crescimento demográfico já não estivesse

\footnotetext{
${ }^{1} \mathrm{O}$ seu texto integral pode ser acessado em http://www.cartadaterrabrasil.org/prt/text.html
} 
em queda; refere-se também aos "padrões dominantes de produção e consumo", como se ignorasse que o produtivismo consumista é inerente ao sistema de mercado regido pela lógica do lucro. Apesar disso, a Carta é um excelente instrumento de mobilização das mentes e das vontades, por seu estilo includente, seu tom otimista e a busca de consenso valorizando o pluralismo. É, portanto, a melhor expressão da "consciência planetária" que hoje se difunde pelo mundo.

No contexto de crise global que ora vivemos, a Carta da Terra ganha enorme atualidade ao sinalizar os caminhos para um outro modo de vida humana no Planeta. Ela não se alinha com o pensamento da "burguesia mundial" (cerca de um bilhão de pessoas que consomem $82 \%$ das riquezas da Terra) cuja esperança reside num desenvolvimento científico e tecnológico capaz de lhe permitir manter o atual padrão de consumo sem risco de esgotamento dos recursos energéticos, mas sim com quem busca construir um modo de produção e consumo voltado não para o crescimento econômico, mas para o bem-estar de todo ser vivo. É o que fazem os diversos movimentos que participam dos Fóruns Sociais Mundiais, ao proclamarem que "outro mundo é possível". Abdicam da utopia produtivista do progresso sem fim, pela utopia da harmonia universal com toda a comunidade de vidaa bela e provocante expressão usada na Carta da Terra para designar o conjunto dos seres viventes.

A consciência planetária não se descola das realidades locais, muito antes pelo contrário: "pensar globalmente e agir localmente" significa, hoje mais do que antes, ter um pé firme na base local e o outro a caminho da uma articulação regional, enquanto os olhos miram as realidades nacionais, continentais e planetárias. Trata-se, pois de uma verdadeira revolução no pensamento e no campo dos valores que regem o comportamento humano. A concepção da pessoa humana como indivíduo livre, que desde o Renascimento europeu tem sido a base dos valores e direitos que regulam as nossas relações com outras pessoas e com a natureza, foi levada ao extremo, como se a pessoa fosse o eixo do mundo. A consciência planetária requer um outro paradigma, no qual o ser humano se veja como parte da grande comunidade de vida, parte importante, sem dúvida, mas não como uma espécie com o direito de dominar as outras. Essa nova forma de consciência precisa apoiar-se numa ética universalista (que inclua os direitos animais e os direitos da Terra) e só terá a ganhar se gerar uma espiritualidade que a anime desde seu interior. 